\title{
Sciendo
}

DOI: $10.2478 /$ jolace-2018-0029

\section{Illustrated Philosophical stories from Norwegian children and youth literature translated into Slovak after 2010}

\author{
Martina Petríková \\ University of Presov, Slovakia \\ martina.petrikova@unipo.sk
}

\begin{abstract}
Among the artistically valuable philosophical stories with illustration which have been translated into Slovak from Norwegian literature for children and youth since 2010 are the books of Jostein Gaarder (Knižka otázok / English - Questions Asked, 2013; Anton a Jonatán /English - Anton and Jonathan, 2014), Jon Fosse (Kant, 2015) and Elisabeth Helland Larsen (Ja som smrt' / English - Life and I: A Story about Death, 2016). The mentioned authors have all published books in which a narrower philosophical function is linked with an implicit aesthetic function. These writers and/as philosophers reflect in their books subjects and issues which are represented in a smaller measure in Slovak intentional literature and take on questions about the meaning of existence in the face of death, whether through experiences with death, or death as an integral component of life or about the boundaries of knowledge. In this contribution we will devote ourselves to selected artistic texts with the philosophical issues of boundaries (between life and death, of knowing) in literary and creative interpretation in order to emphasize that their reflection in literature may lead to more integrated identification of the world of children.
\end{abstract}

Key words: philosophical stories, illustration, Slovak translation, Norwegian literature for children and youth

\section{Introduction}

Since 2010 several artistically valuable philosophical stories for children and youth have been translated from Norwegian into Slovak. Among the books which in the long-term may also become books of "philosophy for children" (Šabík, 2003, pg. 376; compare Lipman, 1988), it is possible to include works by Jostein Gaarder, probably the most well-known contemporary Norwegian writer and philosopher and author of Sophie's World; Jon Fosse, a Nobel Prize nominee for dramatic creation; and lesser known author Elisabeth Helland Larsen.

Jostein Gaarder is a well-known Norwegian writer, who after finishing university studies in Scandinavian languages and theology taught philosophy and devoted himself to literary endeavors. Back in 1991 Gaarder published Sophie's World, a novel on the history of philosophy (not only) for young readers, which 
was also published in several editions in Slovakia, the last in 2002 by the publisher SOFA. Among Gaarder's books intended for children and youth that have been published in Slovak translation since 2010 are Vianočné mystérium (Artforum, 2012, The Christmas Mystery), which reflects the history of Christianity, Knižka otázok (Albatros, 2013, Questions Asked), Anna. Príbeh o klíme a životnom prostredí (Albatros, 2014, The World According to Anna), Anton a Jonatán (Albatros, 2014, Anton and Jonathan) and Pomarančové dievča (Verbarium, 2014; The Orange Girl). Among them are philosophical stories aimed at younger readers age 7 and up (anticipating visualization even with mediation of experienced knowledge), and therefore also the illustrated Knižka otázok and Anton a Jonatán, which can be assigned to the picture books category.

Illustration is also an integral part of Fosse's books for the younger reader. By its name alone, the book from 2005 - Kant (Modrý Peter, 2015) - suggests that it will deal with a philosophical issue. The book, recommended for children 8 years and up, was translated into Slovak by the author's wife, Anna Fosse. Jon Fosse was born in Haugesund, Norway, and studied philosophy, sociology and literary science. At present he devotes himself mainly to writing, including to children's literature. In 2016 he was nominated for the Nobel Prize for Literature.

Elisabeth Helland Larsen is a Norwegian art therapist who uses "clowning around" as an artistic resource in meetings with children in danger (refugees, hospital patients), thus in the close vicinity of death. This fact has also influenced the writer's goals as an author, the ambition to narrow the gap from the subject of death in children's literature, particularly in a book intended for children age 6 years and older, with the name Ja som smrt' (Knižná dielňa, 2016) and published in the Slovak translation of Eva Lavríková.

In the contribution we will devote ourselves to selected artistic texts with the philosophical issue of boundaries (between life and death, of knowledge) in literary and artistic interpretation, in order to emphasize that their reflections in literature may lead to more integrated identification of the world of children.

\section{Theoretical starting points}

Philosophical stories with illustration - philosophical fairy tales, philosophical stories from the life of children, the artistic-instructional story (as well) as a "philosophy for children"1 (Šabík, 2003), or "stories intended for

\footnotetext{
1 We will, under the concept of "philosophy for children", consider in the broader sense of the word those artistic texts which address a philosophical problem or make a philosophical aspect accessible, that is philosophical fairy tales or stories from the life of children or other genres, even though Lipman (1988) understands under this concept texts which originate with a didactic intention in order to become texts for a philosophical discussion of children, which, however, does not exclude the part of artistically valuable texts that also initiate a philosophical discussion.
} 
philosophical discussions of children" (Lipman, 1988) - reflect basic philosophical questions which take part in the problematization of ostensibly simple stories (in fairy tales, in stories from the life of children, or in artistic literature of fact from among artistic and professional literature, etc.). These philosophical questions/issues are associated with life and at the same time the debatable (intended for a "partner discussion") problems of children, since the subject of literature for children is defined by age and the world of children and its issues coalesce with tension from the unknown (Miko, 1980). "Deficits" of being, as well as in knowledge (truth), or (moral) actions can at least can be removed in the longterm. The philosophical issues of children, which also relate to adults, may be resolved conciliatory/harmonically, by obtaining experience or by expanding (the cognitive, emotive type) knowledge mediated by art.

Art is a specific type of interpersonal communication which relays specific information: "The information conveyed during artistic communication is not definable and conveyable by other than artistic resources. Its special character consists in the fact that it doesn't revert to some individual psychic functions, but to the total psychic forces of a person. Art reorganizes this whole and thus creates a new harmony of essential forces (reason, sense and will)." (Brief Dictionary..., 1977, p. 16; according to Kulka, 2008, p. 17).

In their artistic form, illustrated philosophical fairy tales or stories from the life of children are also based on the partnership dialogue of an adult and child, in which the child learns in a playful way to perceive and interpret the world, herself and others in relation to the world, depending on the level and character of her own psychic.

The world in an artistic image, modeled on the principle of a child's point of view, should be fashioned from the viewpoint of the personal needs of the child recipient, and the designing of this picture in the shape of a literary work should be in line with the communication possibilities of the child recipient (Kopál, 1997, p. 20-21). Among basic psychic needs of a child, fulfilled within the family (Matějček, 1994; Maslow, 2014) in which a children's book is met for the first time, are the need for stimulation, a meaningful world, love and security, identity and his or her place in society, or a life outlook (of a better world); but it is necessary to emphasize above all higher cognitive (to know, to understand, to discover) and aesthetic (beauty, symmetry, order) needs, or the need for self-realization.

The reception of artistic literature for children and youth (reading books, looking over book illustrations, discussing a book's themes, problems, etc.) may be a source of diverse stimuli, may stimulate sight, hearing, touch, even speech contact, communication of an adult with the child, the child with an adult and the literary text, thanks to which the child learns to perceive the world with all the senses. Stimuli should be comprehensible and systematic, so that the child (usually through the mother but also by means of the literary image) can understand the 
world and its values, as well as join into such a (meaningful) world. Children's literature mediates images of the subject and social world that the child learns to know "hand-in-hand with the adult", in which he learns to orientate and evaluate himself and others in relation to it (on the axes of love - hate, joy - sorrow, justice - injustice, truth - lie, security - insecurity, heroism - cowardliness, friendship hostility, cooperation - contrariness and the like, compare Zajac, 1980). The child namely expects (emotional) stability, context, a certain measure of regularity and foreseeable phenomena and processes running in his life (and the thematicized) world, thus a meaningful version of the world that she wants to join and at the same time there is along with it tension in the process of creating her own identity.

Literature which shares in the integration of a child into the social environment and in the development of his personality (Zajac, 1980) thematicizes events or states (feelings, thoughts, values), offers positive role models (acting or feeling, thinking and evaluating) or builds them through contrast, but mainly creates the image of a better world or a positive life perspective, which the child also expects in the family in the form of the need for social sharing of an open-ended future.

This means that through literature a child may also fulfil her emotional, cognitive (and philosophical) or social needs. She can look for answers to basic philosophical questions (about knowledge of truth, moral actions, faith, etc.), which the literature asks, so that she is able to answer them in her own life, too.

If we think about a philosophical story which is illustrated, we must emphasize that the illustration as an artistic work is an equal partner of the verbal work. It may ease the process of text acquisition, encourage imagination in regard to independence and the intellect regarding the work (Wróblevska, 1976, p. 50). A child is already in the fifth to eighth year capable of understanding the illustrator's intention, which is the bearer of a position in relation to reality, of enriching and deepening his own position and level of evaluation (Kloss, 1979, p. 32), thus of decoding the meaning of a visual image or even the philosophical aspects "infiltrated" into the image, which is indicated by visualization, and therefore the picture eases the reception of philosophical issues (e.g. pictures of stars, of space as the background for a lonely child or an object, which evoke problems in the relation of a person to infinity, the place of man in the universe, etc.). Namely, it applies that specific perception of objects and phenomena, empirical experience, precludes the creation of ideas and concepts.

Thinking, as a higher cognitive function which is focused on revealing, awakening the relationships and associations between phenomena and which enables knowing the essential and general characteristics of reality, as well as uncovering new characteristics (Kubáni, 1994, p. 29), is built on the results of perception and imagination, thus on visual perceptions and images. 
Texts which are intended for the philosophical discussion of children ("philosophy for children", Lipman, 1988), according to Ann Margaret Sharp (Šarníková, 2014), are focused on issues known from the history of philosophy, and children learn to examine them in a philosophical way. The selected philosophical issues become a means of developing and deepening of selfcorrective thinking.

Texts which are intended for philosophical discussion of children should, according to Sharp (compare Šarníková, 2014), satisfy several criteria. We mediate them in reduced versions with emphasis on the criteria posited in the text, that is, not on the pedagogue, who in the course of literary communication leads the children to a philosophical approach to a thematicized world, or on children as potential recipients who should become a part of the "seeking community":

1. The main literary characters are children, who in the course of the philosophical exploration deepen their own (critical, creative, involved) thinking; they are formed from a cognitive, emotional and social point of view, are capable of being self/critical, self/corrective and in relation to other figures become more sensitive to their experiencing and thinking.

2. A story with a problem, puzzle or riddle should reflect the process of deducing its overall complexity, which we understand such that in the story we are able to identify the causes or origin of problems as tensions, the differing opinions of characters on problems and on their solution, alternative actions and the like. The story should respond to philosophical concepts and processes, thus to the philosophical tradition, as well as to the daily experience (thematicized reality) of the fictional child characters, of common problems of children, so that philosophical examination develops and mediates a dynamic view of the world.

3. A philosophical story may focus on one philosophical aspect but should include as many philosophical of dimensions as possible (ethical, logical, aesthetic, epistemological, metaphysical etc., Lipman, 1988). Even though telling is a typical textual strategy, a text assigned to the context of "philosophy for children" uses philosophical dialogue (controversial, evident and easily perceptible) and philosophical ideas.

Some of the criteria can be applied to selected translated texts, which are in the end texts with the philosophical intention of the (empirical $\rightarrow$ model) author and/or text, since in its artistic form they also fulfill a cognitive, narrower philosophical function, and can thus also be intended for philosophical discussion of potential recipients. An example of an artistic text with philosophical intention is Gaarder's Sophie's World, which Šabík (2003, p. 376) labeled as "philosophy for children" and which is in the subtitle labeled as a "Novel on the History of Philosophy"; that is, it emphasizes the philosophical intention of the author itself. 
We consider texts which are intended for the philosophical discussion of children as texts which may be but do not have to be artistically valuable texts. In any case, it is possible to apply some criteria which are posited on it upon reflection of the artistically valued philosophical stories, if their didactic or educational function will be an implicit function of the aesthetic function.

One of the authors, Jostein Gaarder, who is indirectly a defender of an affective or appellative approach (Eco, 2015; Trávníček, 2007, p. 427) when looking at the value of a work in the history of aesthetic thinking, states that a book lives within us, is again discovered by us upon reading it, and even though an author stands behind a book, it is we who give life to it (Gaarder, 2002, p. 53). He calls attention to the fact that reading books contributes to the building of awareness of a young person, that not only does it expand his horizon, but also the identity of his soul. And he mentions the reason for his own writing, which is found in his works in the form of a subject or theme, and this is the uncertainty of being and the world (Gaarder, 2002, p. 55-56), or accepting responsibility for life (Grečnerová, 2016).

The intention of an artistic text, in line with the considerations of U. Eco (2009; 2015), we consider in the process of textual interpretation as more relevant in comparison with the intention of the empirical author, since his interpretation cannot be used for evaluating the interpretation of the text, that is, not its use for various (let's say also philosophical) purposes outside of literature. His intention namely may also be the ambition to create a text intended for the philosophical discussion of children, thus a "philosophy for children", which in the narrower sense of the word reflects philosophical issues, so that self-corrective thinking of the potential recipient above all is developed. The model author merges with the intention of the text, in which a model reader is located, and he or she may read the book as it was intended in a certain sense, but also such that it provides manifold interpretations. These, however, are controlled by the interior cohesiveness of the text; that is, it is possible to accept each interpretation, if it is confirmed, and to reject it, if another part of the text casts doubts on it (Augustinus: De doctrina christiana 2 - 3; Eco, 2009; Eco, 1995). This means that if a reader interprets a part of the text as a component of the "philosophy for children" in the broader sense of the word, because a philosophical issue (a philosophy of life, the boundary between life and death, the question of death, the boundaries of knowledge, etc., an example may be philosophical questions in Questions Asked) is resolved in the text, but not with a didactic intention, or with the condition that the text develops primarily self-corrective thinking, then its interpretation will be acceptable, if interpretation of the whole work allows for it.

In this way we repeatedly get to the definition of art as communication, which also transmits information by artistic means and which addresses all the psychic forces of a person in order to reorganize them (Kulka, 2008, p. 17). Which leads us to the conviction that the model author, in which a model reader is found as the 
one who, thanks to the philosophical story or fairy tale becomes a harmonic being and aims for integrated identification (not only) of the child's world, and thus a philosophy of this world, merges with the intention of the artistic text, which expresses "love towards wisdom" (philosophical aspect $\rightarrow$ philosophical issue), but in its artistic form does not revert only to thinking as a basic psychic function.

\section{Interpretative penetration into selected texts}

The selected translated texts answer to the needs of potential readers aged 6 8 years old, and the illustration eases their reception, which is notable for their visualization. At the same time, they can be labeled as texts which are not dependent on the intentionality of the text. The issue of children's literature as an integral component of a national literature, according to Peter Zajac (1993, p. 76), does not consist in the question of age but "in the ability in the area where the moment of age is found to hold on to the moment of aesthetic self-transgression, self-projection, non-linearity." This means that a philosophy of life, questions of death and knowledge as the subjects and problems of the selected texts may be the very area which is shaped with regard to the child recipient, but at the same time it indicates a certain measure of non-linearity, which reaches the common horizon of the thematicized life world of children and adults ("compatible existential interest", Zajac, 1993, p. 77) and from which a child or adult selects what they need ("different temperamental interest", Zajac, 1993, p. 77), different contents, which the thematicized world has for the child and for the adult.

This means that not a child character, not a child narrator nor a strategy of text construction (characters, events, surroundings, etc.), but the common horizon of thematicized life of the world of children and adults, which includes a philosophical aspect, is that which would incorporate a "philosophy for children" in a wider sense of the word, but in the end also some texts intended for philosophical discussion of children as a part of children's literature with a special function, if the aesthetic function will be implicit, into the artistically effective literature for children and youth.

\section{The philosophical picture story as an adventure of the mind}

In 2012 Jostein Gaarder published Questions Asked, and thus he wants to inspire the potential recipient to the experienced reading of a story with a philosophical dimension, which can interest adults and children, as well as to their thinking about questions that are difficult to answer even for an adult reader (compare Grečnerová, 2016). The book was published in the Slovak translation of Milan Richter in 2013. Turkish-Norwegian illustrator of children's books, Akin Düzakin, cooperated with Jostein Gaarder on its composition. The artist reconstructs the story of a boy who was left alone after the death of his twin. 
Two basic educational principles are set out in the book. Against the paradigmatic principle, which ensures the familiarization of the philosophical problems, the syntagmatic principle, which can be connected with successively developing picture story, is presented. The paradigmatic principle is connected with the formulation of 48 philosophical questions as philosophical problems - the origin and existence of the world, life on Earth and in space, the cosmos, being and its meaning, the process of thinking and knowing the world, thinking and language, memory, dream and reality, the emotional side of the personality (fear, love of self and others, friendship), values, miracles, the categories of time, ownership, perspective on life, proceedings and the Earth, God, death, etc.: "Where does the world come from? Does something exist forever? Or did everything arise from nothing?" Gaarder, 2013, p. 6; "How can I remember something that happened a long time ago? What does it mean that I forget something? And what is it that I suddenly remember something?" Gaarder, 2013, p. 24; "Why am I alive? Why does the world exist? Why does anything exist?" Gaarder, 2013, p. 44; "Can I love someone else the same as myself?" Gaarder, 2013, p. 48; "What is best and most important in life?" Gaarder, 2013, p. 62).

The picture story of a boy character addresses together with the philosophically (dialogic) constructed learning (by the accumulation of questions which the character of the boy asks and which are also asked of potential readers) by means of illustrations about (the boy - humanity) being, the world and the path to knowing them. The boy in the story with a problem and the experience of loss of his closest other is left alone, becomes more sensitive to stimuli from the exterior and interior world, perceives seemingly obvious things and happenings more problematically. At the same time, he is detached from the known environment of home (picture and a symbol of a house), enters onto a path (picture and a symbol of a road), joins a wider association of being and life, Earth and space, is confronted by the problem of loss or death (image of twins), begins to think about and take an interest in relation to himself, others and the world. The boy, by asking himself, predetermines the process of his individualization or adventure of thinking, so that he looks at the world as at a not self-evident "miracle". The final answer confirms that the boy character, after philosophical confrontation with the situation of loss, establishes his life perspective and asks how he is burdened with his own life. The problem of establishing perspective is also expressed artistically, by a symbolic offer for meditation and its recording, since it acquires the form of open unwritten pages of a notebook, which evoke the future as a tabula rasa.

Gradually developed knowledge, the picture story of a boy quiets through its visualization the tension of seemingly unrelated philosophical problems, which represents the process of philosophical knowing of himself and the world. The aesthetic experience then passes from the confrontation of two types of knowledge and eventually from the inducing of symmetry between the disturbing 
and conciliatory elements, from philosophical questioning on principle issues and to an outline of perspective.

\section{The philosophical picture story as a philosophy of life}

In 2014 Gaarder's philosophical story Anton and Jonathan was published in the Slovak translation of Jarmila Cihová. Akin Düzakin was again the illustrator of the story for readers from the age of 7 and up. The story deals with principle philosophical questions which come at the turning point event in the life of a child, or from the reality of loss in life of an anthropomorphic child's toy. The teddy bear Anton represents the "child's aspect" and becomes the narrator, who from his perspective tells the story about his friendship with the boy Jonathan. He speaks in simple language and style, uses the past tense, which means that the stimulus for telling the story about building the relationship was a major event, an intervention into the corporality (death) of the child character.

The story about the strength of friendship, the intensity of experiencing life, about happiness, is recast into Jonathan's statements about the world, being and relations, on which the teddy bear mediates: "The world belongs to us, he often said. Now is our time. Mammoths and dinosaurs lived here before. But now we are the important ones. Anton added: Well, tell me we're not happy? We can go bicycling all over town and do everything together. I sat in the little basket on the handlebars. I was Jonathan's best friend." (Gaarder, 2014, page not numbered). The pictures of Akin Düzakin, which use the motif of the inseparable pair of the boy and the teddy bear, games and even fantastic events, speak to the intensity of the relationship. The thematicized activities and mimicry games as an imitation of learning, but also the imagination of existential situations (Zajac, 1993, p. 74), which influence the time of childhood, transform the children's world into its optimistic and fantastic metamorphised version, represent the child's philosophy of life.

From the viewpoint of text composition the gradual development of the story occurs in both text and image elements, but at the same time fantastic and playful events are confronted with a non-fictional path into the real world by non-fictional transportation; thus fantasy and reality confront one another. On this road it happens that the child, who is still only learning to recognize boundaries, to separate fantasy and the real world, runs into the mantinel of his own possibilities: "At that moment, when Jonathan saw the big van, I saw it, too. You have to hit the brakes, I thought. Jonathan, hit the brakes! We collided with the white van at full speed, until we hit it. The collision threw Jonathan from the bicycle. And me, too." (Gaarder, 2014, page not numbered). Thus, tension is established in a story with the issue of loss and loneliness of a child element, a teddy bear, which is integrated among other toys. Artistically, the seperateness is expressed by the motif of the teddy bear, which is placed into a corner of the shelf, and its detailed depiction over the next two pages shows the fragility and uncertainty "pressed into the 
corner" of the child being, without those who fill the child's world with their nearness.

The gradually developed knowledge, the picture-book philosophical story of the teddy bear and his boy, is connected to paradigmatically developed knowledge, visually exemplified diverse games as an imitation of knowledge. The tension of the collision and its impacts is attenuated in the text and the artistic element by the recoverable thought which most fully expresses the boy's philosophy of life "Anton, said Jonathan. Well, tell me we aren't happy? The world belongs to us, he often said. Now is our time." (Gaarder, 2014, page not numbered), as well as by the picture with the motifs of friendship and a fantasy dimension of being on the road of life. Fantasy as a method of self-realization of a child is namely a way of assimilating reality through a child's imagination with the expression of personification of the teddy bear. And its acquisition tells of the assimilating tendencies of the child. The aesthetic experience grows from the inducing symmetry between the disturbing (the collision with reality as an expression of inadaptability) and the conciliatory element (assimilation of a philosophy of life).

\section{The philosophical story with illustration as demarcating the boundaries of knowledge}

The philosophical story Kant, which Jon Fosse wrote and Anna Fosse translated, deals with the subject of the universe. A child's fear of the unknown or unfamiliar is the issue at hand. The book, with illustrations by Jakub Milčák, is intended for children from 8 years and up as well as their parents. That which could motivate the selection of issues (thinking over an issue - an unknown or unfamiliar universe, fear of the unknown as incomprehensible or hard to understand content of the mind, thus the boundaries of knowledge) of an intentional book, are already reflected in Kant's statement: "Two things always fill my mind with new and growing admiration and deep respect the more often and more permanently my mind deals with them: the starry heavens above me and the ethical law within me." (Danto, 2008, p. 195)

Kant in his work emphasized that the validity of a categorial imperative depends on social relationships, because it doesn't formulate the present state, but the future one. And therefore, it is possible to understand the thematicized model of a father's behavior, which is a perspective worthy of following, as an offer for the boy character, the son Kristoffer. A prerequisite of accepting such an offer (to read, to educate, to confront his opinions with other opinions and the opinions of philosophers, to shift the boundaries of his knowledge) is free choice or a decision for the future prospect of better education and good knowledge, so that the fear of the unknown is overcome.

In the case of Fosse's text, the majestic as an aesthetic category meets the category of the universe. "The majestic should uplift us in the act of insight; 
reflecting judgement founded on feeling should bring us to the knowledge that we are 'beings of reason', which in this seeming weakness attempt to strengthen me." (Schneider, 2002, p. 63) We can see an analogous tendency in the reflected text, since the boy, who thinks about the universe but also through antinomy demonstrating the deceptive character of reason (see Fosse, 2015, p. 22; compare Solomon, 1996, p. 44), is building his own identity.

At the same time the story deals with the issue of the boundaries of our knowledge, which are according to Kant given by the boundaries of our experience. And the knowledge of the boy, who fears the cosmic theme as a problem at the given stage of life, therefore seems to be unconsummated, and therefore acquiring it is a challenge for the future.

What represents the content of thinking is connected to the category of the mind, thinking about thinking, about the universe and its boundaries, thus the infinite, knowledge and its limits, or handing over or mediating knowledge, of life and dream, existence, thus also philosophy, fear as an emotional reaction to harder or demanding interpretable category.

The childlike questioning about what is now impossible to grasp by thoughts, which surpasses experience, is questioning indirectly focused on the father, or even further, on mediated knowledge, thus on instruction, how and where to search adequately or answers adequate to the age. And even though the answers are indicated more in the form of confrontation of the childish ideas and thinking of an eight-year-old boy (infinite space $\rightarrow$ giant $\rightarrow$ fear, existence - dream) and potentially acquired knowledge (by study of philosophy at university, by reading recommended books, by accepting the knowledge that it is impossible to understand to all), it is clear that "unprepared" knowledge is emphasized as questioning and thinking.

The adult method of alleviating a child's fear is the thoughtful path of a person who knows a lot but mainly who lies next to me in bed and hugs me around the shoulders (Fosse, 2015, p. 20-21). And this is also an instruction for alleviating the fear of a growing boy. Fosse uses the partnership discussion between a father and son to quiet childhood uncertainty, emphasize the need to establish the parental (emotional) role in the life of the child, as well as show the correct method of overcoming the uncertainty caused by insufficient knowledge. The metatext link or references to Kant and his idea on the possibilities of knowing the world offer not only a sketch of Kant's philosophical knowledge (the boundaries of our knowing are given by the boundaries of our experience, and thus the supersensible is principally unknowable; a priori knowledge is independent of experience; reason is capable of submitting proof of thesis and antithesis and the like), but also instruction that it is possible to live with the awareness of "limited" knowledge, because the stage of life offers perspective for the growing of knowledge or a change in the way of thinking: "I once read a book written by a certain Mr. Kant, and 
when I read it, I understood at least a little about why I cannot understand everything. There are things that we do not understand, because we think in the way that we think. When you are a little bigger, you can also read the books of Mr. Kant or you can go study philosophy if you want." (Fosse, 2015, p. 25)

The child tries under the guardianship of an adult to master his fear, which follows from his own way of creating the image of the world and being in it. Modelling the idea of the world namely comes from limited childhood experience, and even the limited reader's experience, knowledge which was mediated to him in time.

Philosophical grasping of the subject and issue of fear of the unknown as majestic content (infinite space) but also the problem of the boundaries of knowledge leads the potential reader to reflections of thinking processes (and their forms - concepts, actions, or judgements) and thinking about thinking, thus methods of our human empowering of reality.

Paradigmatically developed knowledge, namely the repeating of the motifs of imagining, thinking and reading, of fear, space, of knowledge of its borders, are integrated into gradually developed knowledge, the story of the relationship between father and son, which eases the adaptation of the child to unknown experience. The aesthetic experience comes this time from inducing symmetry between the disturbing (fear) and conciliatory elements (the father's and Kant's philosophy, perspective of knowledge).

\section{The philosophical fairy tale with illustration as de-tabooing the subject of death}

In the book of Elisabeth Helland Larsen titled Ja som Smrt' (Life and I: A Story about Death), which was published in 2016 in the translation of Eva Lavríková and with the illustrations of Marine Schneider, the character of death acquires in artistic rendering the untraditional form of a black-haired girl, who travels around the country on a pink bicycle in order to tell about herself and her own firm connection with life: "I am Death. / That's how it is/ life by life, / I am Death." (Helland Larsen, 2016, page not numbered)

Death, who visits animals large and small, at any time and under various natural conditions, tells about her own travels or wandering, as well as about human reactions to her presence in the world. The narrator Death uses comparisons, which are appropriate from the viewpoint of respecting psychicmental individuality of the potential child recipient, proceeding in the process of thinking from the concrete to the abstract. Regarding dying older people, we learn that they are those who are now filled up with life, just as it's possible to be filled up with food (Helland Larsen, 2016, page not numbered); regarding younger people we recognize them for their hair fine as paper, warm hands lost in the hands of Death (Helland Larsen, 2016, page not numbered); of the unborn according to eyes 
wiser than those (Helland Larsen, 2016, page not numbered) which belong to Death. The methods of departing with the personification of Death are depicted as "more acceptable" ways, when Death itself in a difficult moment (of life before death) adapts to who is departing. And so Death and the elderly mutually support one another; Death walks together with children step by step, and some she carries hugged to her chest (Helland Larsen, 2016, page not numbered), and to the unborn she tells about life and love.

Thinking about death in the sense of "all-knowing" Death itself acquires a philosophical character, thinking about ways of human departure, as well as about what will happen after death, about the direction of the last of a person's path. The situation of departures, or their acceptance, which are a problem of the text, is alleviated by the narrator Death, because she brings answers, de-taboos the subject of death and its secrets: "I give answers to all. / With me nothing / is hidden or secret." (Helland Larsen, 2016, page not numbered)

The projection in some statements ("It happens that I must / bang especially hard / on the doors, / which no one wants to open." Helland Larsen, 2016, page not numbered), whether using free verse or even symbols, new meanings associate, so that the text not only answers questions but also asks many others. The point which is the well-considered result of the philosophical consideration about death, inseparable from life and about life in the nearness of death, is a point linked to the conviction on the natural movement in the circle of life, about the alteration of phenomena and processes, of birth and death, the cohabitation of Life and Death: "If I were to stop doing this, / where would a place be found / for everything / that grows and takes root?" (Helland Larsen, 2016, page not numbered)

The author concludes the story about Death harmonically, in the spirit of expectation of the potential addressee, because they do not stand her against life or love, but integrate her into life and love. The child reader learns to understand what is not spoken about in our culture and what even adults have difficulty talking about.

The visual shaping of Death helps in the perception of death in a more acceptable form of a girl with flowers in her hair, as an integral part of the living world, which confirms the writer's answer regarding the interconnection of life and death, about their sisterhood.

Paradigmatically developed knowledge, the cumulating of expressions of death and philosophical questions which follow from the boundary situation, are also expressed by the verse construction of the text. It is possible to connect the gradually developed knowledge to the story of Death on the path. The assimilation of reality by the child's imagination is also expressed in the creative shaping; it eases the specification of death in its more acceptable version for the child and the adult. The aesthetic experience comes this time from the inductive symmetry 
between the disturbing (death) and conciliatory elements (knowledge about the inseparableness of death and life and love).

\section{Conclusion}

The selected artistic texts with philosophical intentions, which aside from the aesthetic function and value, make available a cognitive, philosophical function, resolve principle philosophical problems. They turn not only to thinking, but also to overall psychic strength, so that they create a picture of a better world, or at least a better perspective, so that a child, as well as an adult are directed to an integrated identification of the child's world, thus also its philosophy. The empirical intention of the authors, joined with the ambition to guide the recipient to thinking, is asserted in the intention of the model author and text, which in an artistic way answers the philosophical issue of boundaries (between life and death, knowledge) in literary and creative interpretation, so that it can become an artistically effective component of a "philosophy for children".

\section{Acknowledgement}

This article is a partial outcome of the research project VEGA Literary forms of migration (1/0157/17).

\section{References}

Akin Düzakin (online). Available at: http://www.akinduzakin.com/sample-page/ Cimermanová, I. (2014). Graphic Novels in Foreign Language Teaching. Journal of Language and Cultural Education, 2(2), 85-94.

Eco, U. (2009). Meze interpretace. Transl. L. Nagy. Praha: Karolinum.

Eco, U. (1995). Interpretácia a nadinterpretácia. Transl. Z. Kalnická. Bratislava: Archa.

Eco, U. (2015). Otevřené dílo. Forma a neurčenost v současných poetikách. Transl. Z. Obstová. Praha: Argo.

Fosse, J. (2015). Kant. Ilustr. J. Milčák. Transl. A. Fosse. Levoča: Modrý Peter.

Gaarder, J. (2014). Anton a Jonatán. Ilustr. A. Düzakin. Transl. J. Cihová. Praha: Albatros.

Gaarder, J. (2002). Knihy pre svet, ktorý nemá čitatel’ov? Bibiana. 9(4), 52-56.

Gaardner, J. (2013). Knižka otázok. Transl. M. Richter. Ilustr. A. Düzakin. Praha: Albatros.

Gaarder, J. (2013). To je otázka. Transl. J. Vrbová. Ilustr. A. Düzakin. Praha: Albatros.

Grečnerová, B. (2016). Gaarder, Jostein. Rozhovor. Available at: http://www.iliteratura.cz/Clanek/36501/gaarder-jostein

Helland Larsenová, E. (2016). Ja som Smrt'. Ilustr. M. Schneiderová. Transl. E. Lavríková. Uloža: Knižná dielňa.

Kant, I. (1990). Kritika praktického rozumu. Bratislava: Spektrum. 
Kloss, M. (1979). Ilustrácie obrázkových kníh ako predmet estetického zážitku 5 8 ročných detí. Zborník Slovenskej národnej galérie BIB'75 (pp. 29-32). Bratislava: Tatran.

Kopál, J. (1997). Próza a poézia pre mládež. Teória/poetológia. Nitra: Enigma.

Krátký slovník koncepce pražského týmu pro studium vyjadřovacích a sdělovacích systémů umění. Interní publikace ČSAV. (1977). Praha.

Kubáni, V. (1994). Všeobecná psychológia. Košice: PF UPJŠ v Košiciach.

Kulka, J. (2008). Psychologie umění. 2d ed. Praha: Grada.

Leško, V., Mihina, F. et al. (1999). Dejiny filozofie. Bratislava: Iris.

Lipman, M. (1988). Philosophy Goes to School. Philadelphia: Temple University Press.

Maslow, A. H. (2014). O psychologii bytí. Praha: Portál.

Matějček, Z. (1994). Co děti nejvíce potřebují. Praha: Portál.

Naji, S. (2005). Interview with Ann Margaret Sharp. Available at: http://www.buf.no/en/read/txt/index.php?page=sn-sharp

Solomon, R. C. (1996). Vzostup a pád subjektu alebo od Rousseaua po Derridu. Európska filozofia od r. 1750. Nitra: Enigma.

Schneider, N. (2002). Dejiny estetiky od osvietenstva po postmodernu. Bratislava: Kalligram.

Stehlíková, K. (2007). Fosse, Jon. Rozhovor. Available at: http://www.iliteratura.cz/Clanek/21749/fosse-jon

Šabík, V. (2003). Diskurzy o estetike. Bratislava: Vydavatel'stvo Spolku slovenských spisovatel'ov.

Šarníková, G. (2014). Filozofický text pre deti ako východisko filozofickej diskusie zameranej na rozvoj myslenia a morálneho a sociálneho vedomia diet'at’a. In Ostium. Internetový časopis pre humanitné vedy, 10(4). Available at: http://www.ostium.sk/sk/filozoficky-text-pre-deti/

Trávníček, J. (2007). Koncept čtenáře a čtení - nejkratší možné dějiny. In Dějiny čtení (pp. 403-438). Transl. O. Trávníčková. Brno: Host.

Welsch, W. (1993). Estetické myslenie. Bratislava: Archa.

Wróblevska, D. (1976). Diet'a a kniha dnes. In Zborník Slovenskej národnej galérie $B I B^{\prime} 73$ (pp. 34-40). Bratislava: Tatran.

Zajac, P. (1993). Modely detskej literatúry. In Pulzovanie literatúry (pp. 70-79). Bratislava: Slovenský spisovatel'.

Zajac, P. (1980). Utváranie literárneho vedomia diet’at’a. In Umenie a najmenší (pp. 150-170). Bratislava: Mladé letá. 


\section{Contact}

PaedDr. Martina Petríková, PhD.

Institute of Slovak and Media Studies, Faculty of Arts

University of Presov

17. novembra 1, 08001, Slovakia

martina.petrikova@unipo.sk 